\title{
Hydrogen Fueling Station in Honolulu, Hawaii Feasibility Analysis
}

Porter Hill - INL

Michael Penev - NREL

August 2014

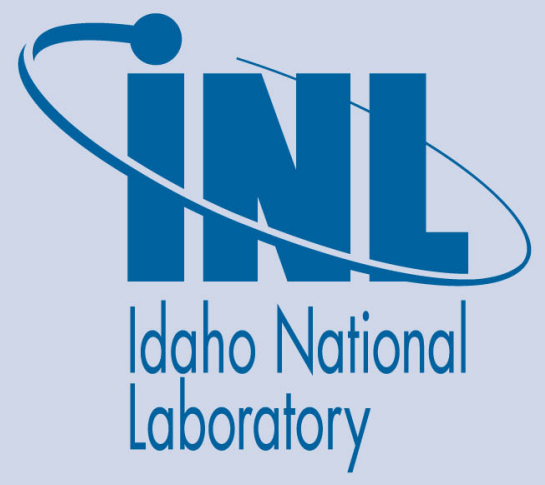

The INL is a U.S. Department of Energy National Laboratory operated by Battelle Energy Alliance 


\section{DISCLAIMER}

This information was prepared as an account of work sponsored by an agency of the U.S. Government. Neither the U.S. Government nor any agency thereof, nor any of their employees, makes any warranty, expressed or implied, or assumes any legal liability or responsibility for the accuracy, completeness, or usefulness, of any information, apparatus, product, or process disclosed, or represents that its use would not infringe privately owned rights. References herein to any specific commercial product, process, or service by trade name, trade mark, manufacturer, or otherwise, does not necessarily constitute or imply its endorsement, recommendation, or favoring by the U.S. Government or any agency thereof. The views and opinions of authors expressed herein do not necessarily state or reflect those of the U.S. Government or any agency thereof. 
INL/EXT-14-31624

Revision 0

\title{
Hydrogen Fueling Station in Honolulu, Hawaii Feasibility Analysis
}

\author{
Porter Hill - INL \\ Michael Penev - NREL
}

August 2014

Idaho National Laboratory Idaho Falls, Idaho 83415

http://www.inl.gov

\author{
Prepared for the
}

U.S. Department of Energy

Office of Energy Efficiency and Renewable Energy, Federal Energy Management Program Under DOE Idaho Operations Office

Contract DE-AC07-05ID14517 


\section{AKNOLEDGMENTS}

This document is a result of significant contributions from the following:

Team Members:

Robert Bellizzi, General Services Administration

Peter Devlin, Department of Energy

James Francfort, Idaho National Laboratory

Porter Hill, Idaho National Laboratory

Michael Penev, National Renewable Energy Laboratory

Mark Reichhardt, Department of Energy

\section{Peer Reviewers:}

Brian Bonner, Air Products

Remy Garderet, Independent Consultant

Joan Ogden, University of California Davis

Herie Soto, Shell 


\section{SUMMARY}

The Department of Energy Hydrogen \& Fuel Cells Program Plan (September 2011) identifies the use of hydrogen for government and fleet electric vehicles as a key step for achieving "reduced greenhouse gas emissions; reduced oil consumption; expanded use of renewable power ...; highly efficient energy conversion; fuel flexibility ...; reduced air pollution; and highly reliable grid support." This report synthesizes several pieces of existing information that can inform a decision regarding the viability of deploying a hydrogen $\left(\mathrm{H}_{2}\right)$ fueling station at the Fort Armstrong (HI0013zz) site in Honolulu, Hawaii. The hydrogen fueling station will be publicly accessible and used to fuel light-duty vehicles, including both General Services Administration fleet and non-General Services Administration fleet vehicles, and other fuel cell transportation technologies that are being deployed in the Honolulu area (such as fuel cell buses and plug-in paratransit buses).

The envisioned facility would consist of a premium covered parking lot, a roof-mounted photovoltaic solar array, and a small $\mathrm{H}_{2}$ production and distribution station similar to other established $\mathrm{H}_{2}$ fueling stations in California. A 1.4-acre, roof-mounted photovoltaic solar field that produces about $700 \mathrm{~kW}$ of power per day can sustain an electrolyzer that is capable of producing roughly 65 $\mathrm{kg}$ of $\mathrm{H}_{2}$ per day without being overly dependent on the electric grid. The intent is to tie the photovoltaic solar array to the electrical grid and to one or more nearby third-party electricity consumers (i.e., most likely a co-located Federal Building) and effectively use the third-party consumer and the grid as an energy storage device. All required equipment is commercially available and can be easily procured and installed within a lead time of one calendar year.

With a $65-\mathrm{kg}$ per day electrolyzer and an average demand of $80 \%$ utilization, the $\mathrm{H}_{2}$ refueling station could support roughly 85 to 100 vehicles. About 148 government-owned electrical and gas-powered "cars" located near the proposed $\mathrm{H}_{2}$ fueling station could easily be transitioned to $\mathrm{H}_{2}$ fuel cell-powered vehicles. Another 293 sport utility vehicles and light-duty trucks are also candidates for transition and fueling station use, as well as a large fleet of public transportation vehicles such as busses. This makes the Fort Armstrong (HI0013zz) site very attractive.

This facility is intended to be a flagship-type installation, setting the example and establishing a renewable $\mathrm{H}_{2}$ infrastructure in Hawaii for other government and private entities to follow. It is assumed that GSA would not own and operate the station but rather enter into a lease agreement with an entity to own and maintain the fueling station. The objective is to establish an $\mathrm{H}_{2}$ production concept that can be replicated at other sites throughout the islands to produce affordable $\mathrm{H}_{2}$ at a price comparable to fossil fuels and in a way that the consumer cost of $\mathrm{H}_{2}$ per kg will not vary from station to station.

In accordance with the information and analysis contained herein, to produce an initial rate of return of $4 \%$ on the $\mathrm{H}_{2}$ fueling station, the cost at which $\mathrm{H}_{2}$ must be sold to recuperate capital expenditures and operations and maintenance costs, following the sale of excess solar-based power and the revenue received for covered parking, is $\$ 13.00$ per $\mathrm{kg}$. In this analysis, it was assumed that a single kilogram of $\mathrm{H}_{2}$ can power a $\mathrm{H}_{2}$ fuel cell vehicle for $\sim 60$ miles, which is a conservative estimate. Considering that gasoline-powered vehicles average 
approximately 24 miles per gallon in fuel economy, a single $\mathrm{kg}$ of $\mathrm{H}_{2}$ is equivalent to more than two gallons of gasoline when fuel cell energy efficiency is considered.

Beyond the economic factors, an $\mathrm{H}_{2}$ fueling station in Honolulu, Hawaii, offers the following important benefits:

1. Supports the President's clean energy strategy to reduce greenhouse gas emission, reduce dependence on foreign oil, and place 1 million electric vehicles on the road

2. Supports both the Hawaii $\mathrm{H}_{2}$ Initiative $\left(\mathrm{H}_{2} \mathrm{I}\right)$ and $\mathrm{H}_{2} \mathrm{USA}$, the public, private partnership launched by DOE and industry in 2013 to address the challenge of $\mathrm{H}_{2}$ infrastructure

3. Establishes Federal/General Services Administration leadership in the zero emission vehicle and fuel cell electric vehicle arena

4. Permits the leasing of fuel cell electric vehicles by General Services Administration on Oahu

5. Informs potential stakeholders that $\mathrm{H}_{2}$ fueling stations are real and encourages the appropriation and allocation of funds for other zero emission vehicles beyond just battery electric vehicles

6. Fort Armstrong (HI0013zz) becomes the 'anchor tenant' for fuel cell vehicle growth and catalyzes development of the Oahu infrastructure toward an initial rollout of six public $\mathrm{H}_{2}$ fueling stations

7. Sends a serious message to fuel cell electric vehicle automakers to support the growing demand for zero emission vehicles/fuel cell electric vehicles in Hawaii.

This report was funded by GSA and the Energy Departments' Office of Energy Efficiency and Renewable Energy (EERE) and prepared by engineers form Idaho National Laboratory and National Renewable Energy Laboratory, and reviewed by experts from industry, gas providers and the utility company in HI. The effort was coordinated between EERE's Fuel Cell Technologies Office and Federal Energy Management Program Office. It is recommended that the program proceed with pursuing the detailed design and implementation of an $\mathrm{H}_{2}$ fueling station at the Fort Armstrong (HI0013zz) site in Honolulu, Hawaii. 


\section{CONTENTS}

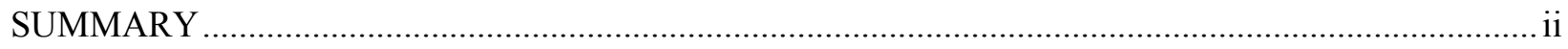

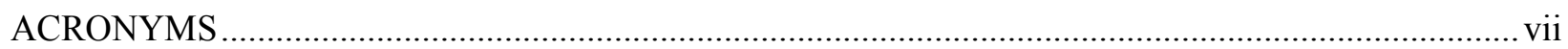

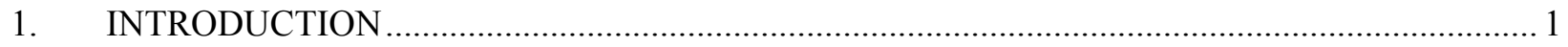

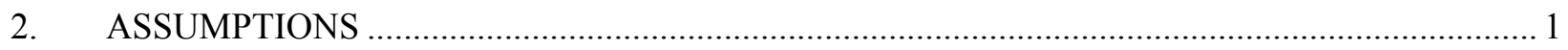

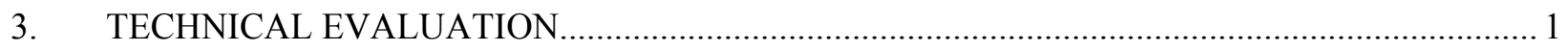

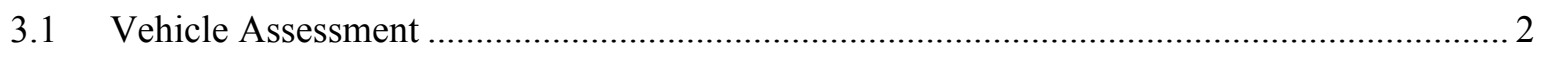

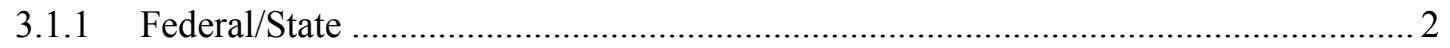

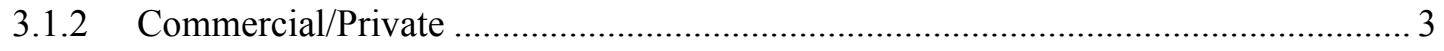

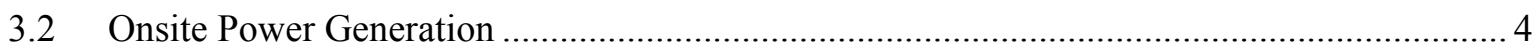

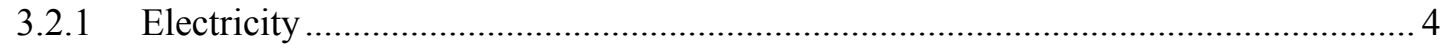

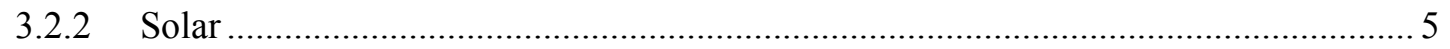

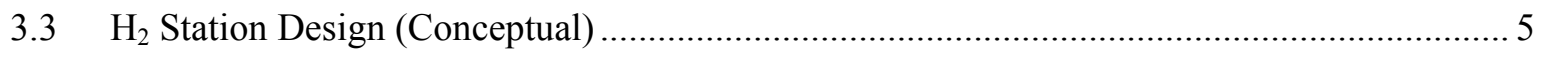

3.3.1 High-Level Station Configuration (Conceptual) .................................................... 6

3.3.2 Equipment Needs and Commercial Availability .................................................. 7

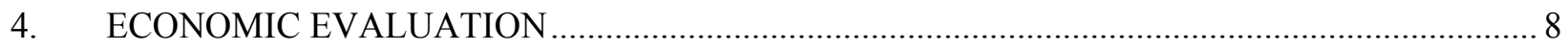

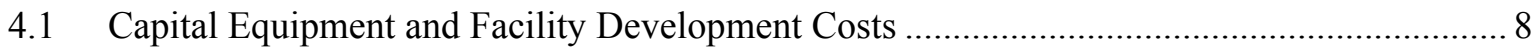

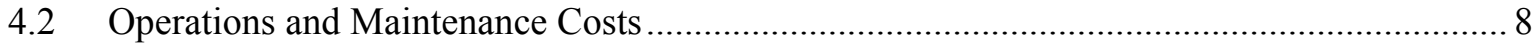

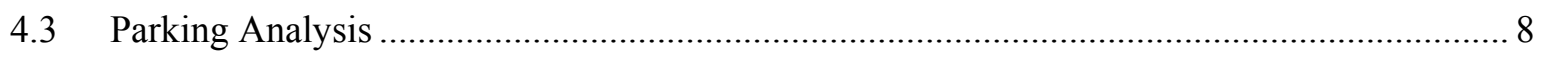

4.4 Income and Expenditure Projections (15 years) …......................................................... 9

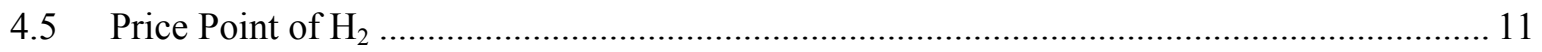

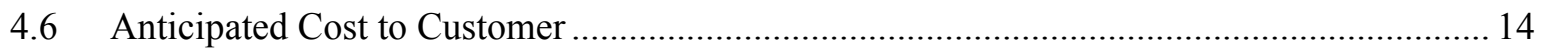

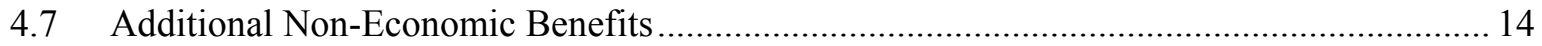

5. CONCLUSION/RECOMMENDED PATH FORWARD ....................................................... 15

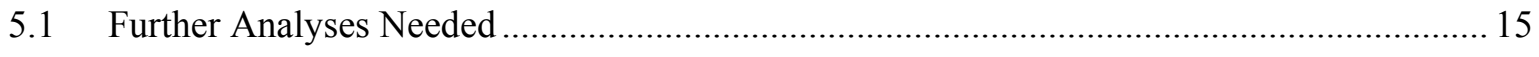

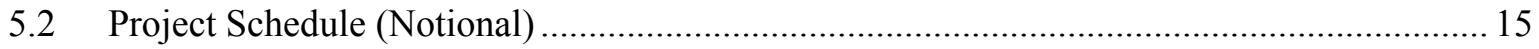




\section{FIGURES}

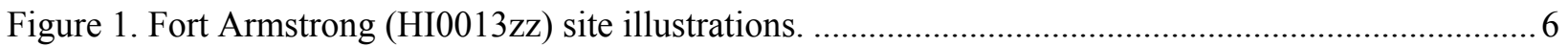

Figure 2. High-level schematic of the proposed $\mathrm{H}_{2}$ fueling station. ................................................. 7

Figure 3. Estimated net present value and initial rate of return versus the percentage of annual

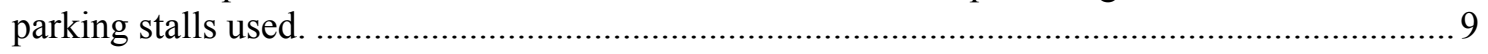

Figure 4. The net present value and initial rate of return for 75\% parking occupancy........................... 14

\section{TABLES}

Table 1. Government agency fleet vehicles. ............................................................................... 2

Table 2. Government vehicles "preferred" for replacement. ..................................................................... 3

Table 3. Average 2012 electricity rates for Honolulu, Hawaii. ................................................................ 4

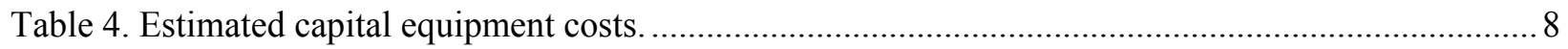

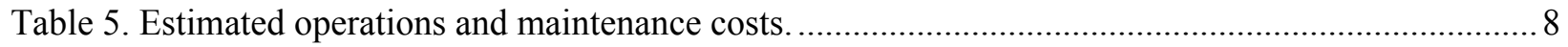

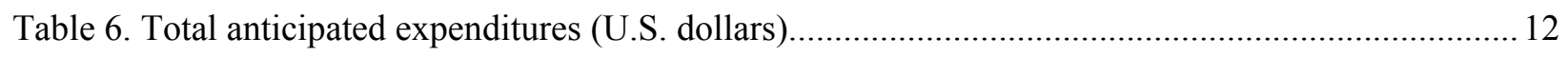

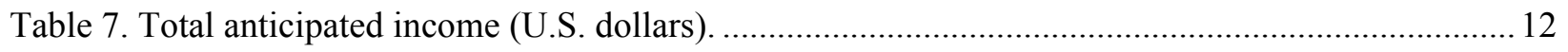

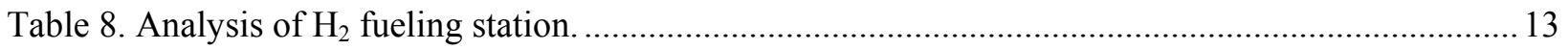

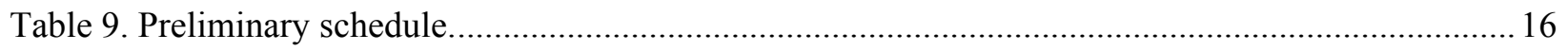




\section{ACRONYMS}

FCEV fuel cell electric vehicle

GSA General Services Administration

$\mathrm{H}_{2} \quad$ hydrogen

HECO Hawaii Electric Company

IRR initial rate of return

NPV net present value

O\&M operations and maintenance

PV photovoltaic

ZEV zero emission vehicle 


\section{Hydrogen Fueling Station in Honolulu, Hawaii Feasibility Analysis}

\section{INTRODUCTION}

The Department of Energy Hydrogen \& Fuel Cells Program Plan (September 2011) identifies the use of hydrogen for government and fleet electric vehicles as a key step for achieving "reduced greenhouse gas emissions; reduced oil consumption; expanded use of renewable power ...; highly efficient energy conversion; fuel flexibility ...; reduced air pollution; and highly reliable grid-support." The plan document also set the following milestones to achieve:

- 5,000-hour (service life of vehicle or about 150,000 miles) fuel system durability

- 300-mile driving range between fueling

- Fueling rates of $1.67 \mathrm{~kg} /$ minute

- Fuel costs of $\$ 2$ to $4 /$ gasoline gallon equivalent, which can equate to as high as $\$ 6$ to $12 / \mathrm{kg}$ for hydrogen considering the advantages in fuel economy.

The Renewable Fuel Standard, established under the Energy Policy Act of 2005 and expanded under the Energy Independence and Security Act of 2007, mandates that fuel makers meet a minimum percentage of renewable fuel production over the next several years. The Renewable Fuel Standard lays the foundation for achieving significant reductions of greenhouse gas emissions by using renewable fuels, to reduce imported petroleum, and for encouraging the development and expansion of our nation's renewable fuels sector.

This report synthesizes several pieces of existing information that can inform a decision regarding the viability of deploying a hydrogen $\left(\mathrm{H}_{2}\right)$ fueling station at the Fort Armstrong (HI0013zz) site in Honolulu, Hawaii. The analysis documented herein is not extremely detailed, but it identifies pieces of relevant information at a level sufficient to provide a basis for decision making.

\section{ASSUMPTIONS}

The following assumptions were used to conduct the feasibility analysis presented herein:

1. Fleet vehicles are replaced every 5 to 7 years, depending on the type of vehicle

2. Only those fleet vehicles operated and maintained within the immediate vicinity of the $\mathrm{H}_{2}$ fueling station are candidates for replacement under the proposed effort

3. Fleet vehicles travel approximately 25 miles per day

4. Gas-powered vehicles can travel approximately 24 miles on one gallon of gas

5. Hydrogen-fueled vehicles can travel up to 80 miles on one kilogram of $\mathrm{H}_{2}$

6. A contractual agreement can be reached with a third-party electrical consumer (i.e., co-located federal and state office building) to sell excess solar power at $\$ 0.30 / \mathrm{kWh}$, which is equal to the General Services Administration (GSA) price for purchasing electricity from the local power utility.

\section{TECHNICAL EVALUATION}

This section analyzes the technical considerations of deploying an $\mathrm{H}_{2}$ fueling station at Fort Armstrong (HI0013zz) in Honolulu, Hawaii. The analysis provides reasonable assurance that no significant factor affecting its viability has been omitted. 


\subsection{Vehicle Assessment}

\subsubsection{Federal/State}

The Federal government maintains a fleet of just over 2,700 vehicles on the island of Oahu; however, not all of the vehicles are considered "preferred" for potential replacement with an $\mathrm{H}_{2}$-fueled vehicle to be serviced by the Fort Armstrong (HI0013zz) fueling station. Table 1 shows the agencies that have government vehicles. Those agencies shown in gray are considered less preferred under this feasibility study because the agencies are located more than 2 miles away from the Fort Armstrong (HI0013zz) site and may not participate due to the inconvenience of the fueling station.

Table 1. Government agency fleet vehicles.

\begin{tabular}{|c|c|c|c|}
\hline Agency & Vehicles in Fleet & Eligible & $\begin{array}{c}\text { Potential } \\
\text { Conversion }\end{array}$ \\
\hline 10 - Department of Justice & 2 & $\mathrm{Y}$ & 2 \\
\hline 12 - Department of Agriculture & 64 & $\mathrm{Y}$ & 64 \\
\hline 13 - Department of Commerce & 37 & $\mathrm{Y}$ & 37 \\
\hline 14 - Department of Interior & 127 & $\mathrm{Y}$ & 127 \\
\hline 15 - Judiciary & 5 & Y & 5 \\
\hline 16 - Department of Labor & 24 & $\mathrm{Y}$ & 24 \\
\hline 17 - Department of Navy & 1,001 & $\mathrm{~N}$ & 0 \\
\hline 19 - Department of State & 4 & $\mathrm{Y}$ & 4 \\
\hline 20 - Department of Treasury & 14 & $\mathrm{Y}$ & 14 \\
\hline 21 - Department of Army & 961 & $\mathrm{~N}$ & 0 \\
\hline 24 - Office of Personnel Management & 23 & $\mathrm{Y}$ & 23 \\
\hline 28 - Social Security Administration & 1 & $\mathrm{Y}$ & 1 \\
\hline 36 - Department of Veterans Affairs & 55 & $\mathrm{Y}$ & 55 \\
\hline 45 - Equal Emp. Opportunity & 1 & $\mathrm{Y}$ & 1 \\
\hline 47 - GSA & 6 & $\mathrm{Y}$ & 6 \\
\hline 49 - National Science Foundation & 16 & $\mathrm{~N}$ & 0 \\
\hline 57 - Department of Air Force & 86 & $\mathrm{~N}$ & 0 \\
\hline 68 - Environmental Protection & 1 & $\mathrm{Y}$ & 1 \\
\hline 69 - Department of Transportation & 68 & $\mathrm{Y}$ & 68 \\
\hline 70 - Department of Homeland Security & 96 & Y & 96 \\
\hline 73 - Small Business Administration & 1 & $\mathrm{Y}$ & 1 \\
\hline 75 - Department of Health and Human Services & 5 & $\mathrm{Y}$ & 5 \\
\hline 77 - GSA Hawaii Office & 2 & Y & 2 \\
\hline 80 - National Aeronautics and Space Administration & 10 & $\mathrm{~N}$ & 0 \\
\hline 86 - Housing and Urban Development & 1 & $\mathrm{Y}$ & 1 \\
\hline 89 - Department of Energy & 4 & Y & 4 \\
\hline 96 - Corps of Engineers & 56 & $\mathrm{~N}$ & 0 \\
\hline 97 - Department of Defense & 54 & $\mathrm{~N}$ & 0 \\
\hline Total & 2,725 & & 541 \\
\hline
\end{tabular}


Table 2 shows a breakdown of the "preferred" vehicles, by type, currently in the government fleet.

Table 2. Government vehicles "preferred" for replacement.

\begin{tabular}{|c|c|c|c|c|c|c|c|c|}
\hline Agency & $\begin{array}{l}\text { Vehicles } \\
\text { in Fleet }\end{array}$ & Cars & $\begin{array}{c}\text { SUV/ } \\
\text { Van }\end{array}$ & Pickup & E-car & E-Pickup & E-SUV & UNK \\
\hline 10 - Department of Justice & 2 & 1 & 1 & 0 & 0 & 0 & 0 & 0 \\
\hline 12 - Department of Agriculture & 64 & 22 & 28 & 10 & 3 & 1 & 0 & 0 \\
\hline 13 - Department of Commerce & 37 & 2 & 15 & 16 & 0 & 0 & 1 & 3 \\
\hline 14 - Department of Interior & 127 & 13 & 36 & 72 & 3 & 0 & 2 & 1 \\
\hline 15 - Judiciary & 5 & 2 & 3 & 0 & 0 & 0 & 0 & 0 \\
\hline 16 - Department of Labor & 24 & 5 & 5 & 4 & 2 & 0 & 0 & 8 \\
\hline 19 - Department of State & 4 & 1 & 3 & 0 & 0 & 0 & 0 & 0 \\
\hline 20 - Department of Treasury & 14 & 9 & 4 & 0 & 0 & 0 & 0 & 1 \\
\hline 24 - Office of Personnel Management & 23 & 23 & 0 & 0 & 0 & 0 & 0 & 0 \\
\hline 28 - Social Security Administration & 1 & 1 & 0 & 0 & 0 & 0 & 0 & 0 \\
\hline 36 - Department of Veterans Affairs & 55 & 21 & 21 & 6 & 4 & 0 & 0 & 3 \\
\hline 45 - Equal Emp. Opportunity & 1 & 1 & 0 & 0 & 0 & 0 & 0 & 0 \\
\hline 47 - General Services Administration & 6 & 0 & 0 & 1 & 4 & 0 & 1 & 0 \\
\hline 68 - Environmental Protection & 1 & 1 & 0 & 0 & 0 & 0 & 0 & 0 \\
\hline 69 - Department of Transportation & 68 & 9 & 28 & 25 & 3 & 0 & 3 & 0 \\
\hline 70 - Department of Homeland Security & 96 & 12 & 45 & 36 & 1 & 0 & 0 & 2 \\
\hline 73 - Small Business Administration & 1 & 1 & 0 & 0 & 0 & 0 & 0 & 0 \\
\hline 75 - Department of Health and Human Services & 5 & 0 & 3 & 0 & 2 & 0 & 0 & 0 \\
\hline 77 - GSA Hawaii Office & 2 & 2 & 0 & 0 & 0 & 0 & 0 & 0 \\
\hline 86 - Housing and Urban Development & 1 & 0 & 1 & 0 & 0 & 0 & 0 & 0 \\
\hline 89 - Department of Energy & 4 & 0 & 0 & 2 & 0 & 1 & 1 & 0 \\
\hline Total & 541 & 126 & 193 & 172 & 22 & 2 & 8 & 18 \\
\hline
\end{tabular}

Assuming that all existing electrical and gas-powered "cars" (see columns "Cars" and "E-cars") could be transitioned easily to $\mathrm{H}_{2}$-powered "cars," a minimum of 148 vehicles would need hydrogen to be provided by the proposed $\mathrm{H}_{2}$ fueling station. Based on the presumed average distance of 25 miles per day, or about 0.4 to 0.5 kilograms of $\mathrm{H}_{2}$ per day, the fueling station would need to produce 75 to $80 \mathrm{~kg}$ of $\mathrm{H}_{2}$ each day to meet this demand. The amount of $\mathrm{H}_{2}$ that can be produced at Fort Armstrong (HI0013zz) will be limited to the size of the site and may not be able to produce the $\mathrm{H}_{2}$ to satisfy the demand if all 148 vehicles. The following sections provide the necessary information to determine how much $\mathrm{H}_{2}$ can be produced at the Fort Armstrong (HI0013zz) site; this information also indicates the potential for future growth opportunities.

\subsubsection{Commercial/Private}

Public transportation (such as busses) is another possible user for the $\mathrm{H}_{2}$ fueling station. A bus can consume between 25 to $35 \mathrm{~kg}$ of $\mathrm{H}_{2}$ per day; therefore, they would cause greater demand on the $\mathrm{H}_{2}$ production infrastructure.

It is assumed that the demand for $\mathrm{H}_{2}$ production for non-GSA fleet vehicles or private vehicles could be accommodated as the $\mathrm{H}_{2}$ infrastructure expands. For this feasibility study, it is assumed that a private vehicle and a government vehicle would be driven similar distances with the same demands. The calculations described in the following sections determine the amount of $\mathrm{H}_{2}$ that can be produced at the Fort Armstrong (HI0013zz) site, thus projecting the number of private and government vehicles that feasibly can be accommodated. 


\subsection{Onsite Power Generation}

Onsite power generation using renewable energy is the most preferred mechanism for $\mathrm{H}_{2}$ production. Solar is an obvious option; however, the team also investigated the potential use of steam methane reforming and shipping $\mathrm{H}_{2}$ from the main land. Both the steam methane reforming and shipping options were shown to be very expensive and unfeasible for the fueling station. This leaves two options for providing electricity for operation of the $\mathrm{H}_{2}$ fueling station: (1) electrical power produced by a photovoltaic (PV) solar array or (2) electrical power purchased from Hawaiian Electric Company (HECO). It is assumed that electrical power will be required at all times, with a near constant load demand because the intent is to produce $\mathrm{H}_{2}$ continuously. This section investigates the options of both a direct grid tie and a partnership with an assumed adjacent third-party consumer, where excess power produced by the PV array can be sold for a higher price than the price offered to sell excess power back to HECO.

\subsubsection{Electricity}

There is only one electric company on Oahu - HECO. HECO has six separate billing rates that are based on the "category" of customer purchasing the electricity. Electricity rates vary by category because they are based on the cost of serving each customer need. There are no adjustments for peak or off-peak usage. Average costs are calculated by dividing the total revenue by the total $\mathrm{kWh}$ sold for each category during the year. Average rates for each category are shown in Table 3.

Table 3. Average 2012 electricity rates for Honolulu, Hawaii.

\begin{tabular}{lr} 
Rate Schedule & $\mathbf{2 0 1 2}$ Average Cost per kWh \\
\hline Residential & $\$ 0.351$ \\
"G" Small Power Use Business & $\$ 0.365$ \\
"J" Medium Power Use Business & $\$ 0.317$ \\
"P" Large Power Use Business & $\$ 0.301$ \\
"DS" Large Power Use Business, Directly Served & $\$ 0.280$ \\
"F" Street and Park Lighting & $\$ 0.329$ \\
\hline
\end{tabular}

According to the HECO website (www.hawaiianelectric.com), the high cost of fossil fuel used to produce electricity accounts for more than $50 \%$ of the purchase price. During 2012, fuel costs increased, resulting in a corresponding increase in the cost of electricity for the customer. Because electricity rates depend on a constantly variable fuel charge, it is nearly impossible to predict future costs; the cost follows the "spot" cost of oil.

The isolated geographic location of the Hawaiian Islands also contributes to the higher cost of electricity, because Hawaii does not have any nearby utility companies from which to draw power in the event of a problem. For system reliability, Hawaii must have reserve generating capacity and multiple distribution routes. Electricity rates include the revenue necessary to cover those costs.

The electrical power needed to operate the proposed $\mathrm{H}_{2}$ fueling station can be purchased from HECO at a contracted GSA rate of $\$ 0.30$ per $\mathrm{kWh}$, similar to the price paid by Large Power Use Businesses (see Table 3). Approximately 1,300 MWh of electricity is required per year to operate the electrolyzer. Of that, $600 \mathrm{MWh}$ are provided directly from the PV panels during the day, and $700 \mathrm{MWh}$ are provided by the grid during the night. The PV panels over-produce electricity by $680 \mathrm{MWh}$ per year, this electricity can be used as cost avoidance for the fueling station if sold to federal facilities or $3^{\text {rd }}$ party in the vicinity and then purchased back from the grid during the night. Considering the overall use the electrolyzer operates in a net-zero manner, as it uses direct solar electrons, and at night it uses timeshifted electrons via grid sales and buy backs. The proposed Fort Armstrong station does not use much net electricity from the grid; therefore the price of oil will not be a large impact to the project. In fact if 
oil becomes more expensive, hydrogen could be sold at a higher price per kilogram, thus benefitting the project.

\subsubsection{Solar}

An important component of this feasibility study is the generation of $\mathrm{H}_{2}$ using electricity produced by an array of PV solar cells. Hawaii is located near the equator and experiences approximately 274 sunny days a year. This fact alone makes PV solar power a viable option for providing electricity to the $\mathrm{H}_{2}$ fueling station. Assuming that the majority of the primary parking area at the Fort Armstrong (HI0013zz) site (approximately 1.4 acres) is available and could be used for covered parking with roof-mounted PV solar panels, the resulting array would yield about $700 \mathrm{~kW}$ of usable electric power. A conceptual view of this can be found in Section 3.3.1.

However, two notable short-comings limit the potential use of solar power at the fueling station: (1) solar power can only be accessed during daylight hours, and (2) the size of the lot limits the amount of $\mathrm{H}_{2}$ that can be produced given the energy production potential of the resulting 1.4-acre PV solar array. Grid-based electricity also will be incorporated into the design to facilitate 24-hour $\mathrm{H}_{2}$ production and to meet the additional electrical demands of the station. The photovoltaic (PV) array is rated at $700 \mathrm{~kW}$, and the electrolyzer capacity is $187 \mathrm{~kW}$. If the electrolyzer is working at full power and the solar is at full output, $513 \mathrm{~kW}$ of access power would be produced. The worst case would be if $\mathrm{H}_{2}$ storage is full (i.e., electrolyzer is off), while the PV is producing $700 \mathrm{~kW}$, that would be offloaded to the grid. Rather than sell the excess power back to HECO at a reduced rate of $\$ 0.20 / \mathrm{kWh}$ to turn around and buy the same power back at night at a higher rate, it is assumed that an adjacent consumer facility would be available and willing to establish a partnership to buy the excess PV power for the same or lower price that they are buying power from HECO (i.e., $\$ 0.30 / \mathrm{kWh}$ ). By making this arrangement with an adjacent facility, the $\mathrm{H}_{2}$ fueling station would sell about $683,000 \mathrm{kWh}$ of power to the consumer facility, while buying that same amount of power back to operate the electrolyzer during the night. This would save the station about $\$ 86,300$ per year (given the exchange rate with HECO), while not costing the adjacent consumer facility anything .

The impact of installing a PV solar array on the cost of the fueling station is significant; however, it is an environmentally friendly alternative that will reduce dependence on fossil fuel. Integration of PV solar technology will also increase the public's perception of renewable $\mathrm{H}_{2}$ production as a viable alternative to traditional $\mathrm{H}_{2}$ production, entice local government entities, and help garner the political support of environmentally sensitive federal agencies.

\section{3 $\quad \mathrm{H}_{2}$ Station Design (Conceptual)}

A 1.4-acre parking lot and adjacent land area at Fort Armstrong (HI0013zz) has been identified as the preferred site for the proposed $\mathrm{H}_{2}$ fueling station in Honolulu, Hawaii (see Figure 1). Fort Armstrong (HI0013zz) is adjacent to Ala Moana Boulevard (i.e., the main route to Waikiki), downtown Honolulu, Honolulu International Airport, and almost all state and local government offices. This includes the Offices of State Judges, State Senators and Representatives, most State Agencies, the Governor's Office, the U.S. Postal Service, and the Prince Jonah Kuhio Kalanianaole Federal Building, which houses the U.S. District Court for the State of Hawaii; the Offices of Federal Judges, U.S. Senators and Representatives; and the Branch Offices of numerous Federal Agencies. Ala Moana Boulevard is also near the bus parking lot and is a main route for tourist buses, trolleys, and taxis. This site is ideal for both paid parking to offset the cost of $\mathrm{H}_{2}$ and for providing maximum public exposure to an all renewable $\mathrm{H}_{2}$ fueling station.

\footnotetext{
${ }^{\text {a }}$ This approach will require an interconnect requirements study
} 

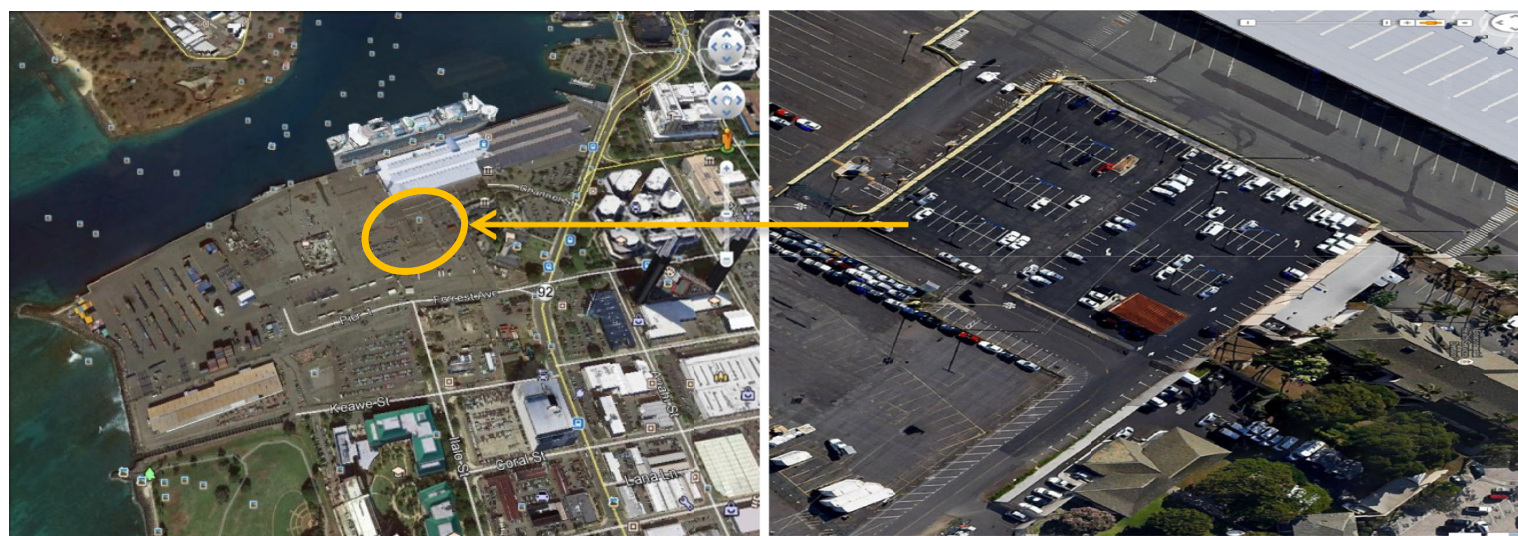

Figure 1. Fort Armstrong site illustrations.

\subsubsection{High-Level Station Configuration (Conceptual)}

As noted above, the $\mathrm{H}_{2}$ fueling station will be powered by a combination of a roof-mounted fix-tilt PV solar array and an integrated connection to the Hawaii electrical grid. To facilitate the use of PV solar technology to produce $\mathrm{H}_{2}$, the project proposes utilizing the unused space of the nearly 1.4-acre lot at Fort Armstrong (HI0013zz) for publically accessible covered parking. Covered parking would allow continued use of the lot for premium parking, while still providing the solar footprint needed to produce the $\mathrm{H}_{2}$. It is estimated that the resulting structure could produce approximately 1,288 $\mathrm{MWh}$ of electricity per year as a power source for the fueling station, while also serving as a potential revenue source (i.e., paid parking structure) to recover capital and operating expenses.

A 1.4-acre PV solar field producing about $700 \mathrm{~kW}$ peak power per day can sustain an electrolyzer that is capable of producing roughly $65 \mathrm{~kg}$ of $\mathrm{H}_{2}$ per day. With this conceptual design, the PV solar array will produce enough power during the day to continually operate the electrolyzer. As noted above, the intent is to tie the PV solar array to the grid and to one or more nearby, third-party electricity consumers (most likely a co-located Federal building). This would be done so that when excess power is produced, it can be sold to a third-party at the same rate it would cost them to purchase power from the utility, then the $\mathrm{H}_{2}$ fueling station can repurchase the electricity from HECO (as needed) during non-sunlight hours. This approach allows the $\mathrm{H}_{2}$ fueling station to use the third-party consumer and the grid as an energy storage device.

The envisioned station itself is expected to be similar to other established $\mathrm{H}_{2}$ fueling stations and will occupy a very small fraction of the Fort Armstrong (HI0013zz) site beneath the PV solar array. The station consists of power electronics that receive and modulate electricity from the PV solar array and provide it to the electrolyzer. Potable water is assumed to be available onsite and will be piped to the electrolyzer, where it is first purified then separated using electrolysis into hydrogen and oxygen gas. The hydrogen stream is fed to a series of hydrogen bulk storage tanks, which, in turn, feed a refueling pump that is used to fill $\mathrm{H}_{2}$-powered vehicles. The oxygen stream is vented to the atmosphere as a harmless gas. With a $65-\mathrm{kg}$ per day electrolyzer and an average demand of $80 \%$ utilization, the refueling station could support roughly 85 to 100 vehicles, assuming they burn between 0.5 and $0.6 \mathrm{~kg}$ of $\mathrm{H}_{2}$ per day. Figure 2 provides a high-level schematic of the envisioned facility.

No water storage is required onsite because it is assumed the water utility is accessible and has sufficient storage. The system can consume potable water and will consume about 45,000 gallons of water per year and according to the board of water supply website (www.hbws.org/cssweb) the cost water is $\$ 4.95$ per 1,000 gallons. This equates to about $\$ 225$ in water cost per year and is therefore negligible at this point. 
This concept of a fueling station is intended to be designed as an autonomous fueling station in order to minimize the cost of personnel to man the station. An operation and maintenance contract will be required to ensure continued operation but there will not be an attendant at the location once sufficient training is completed. The cost of this training is incorporated into the annual O\&M costs.

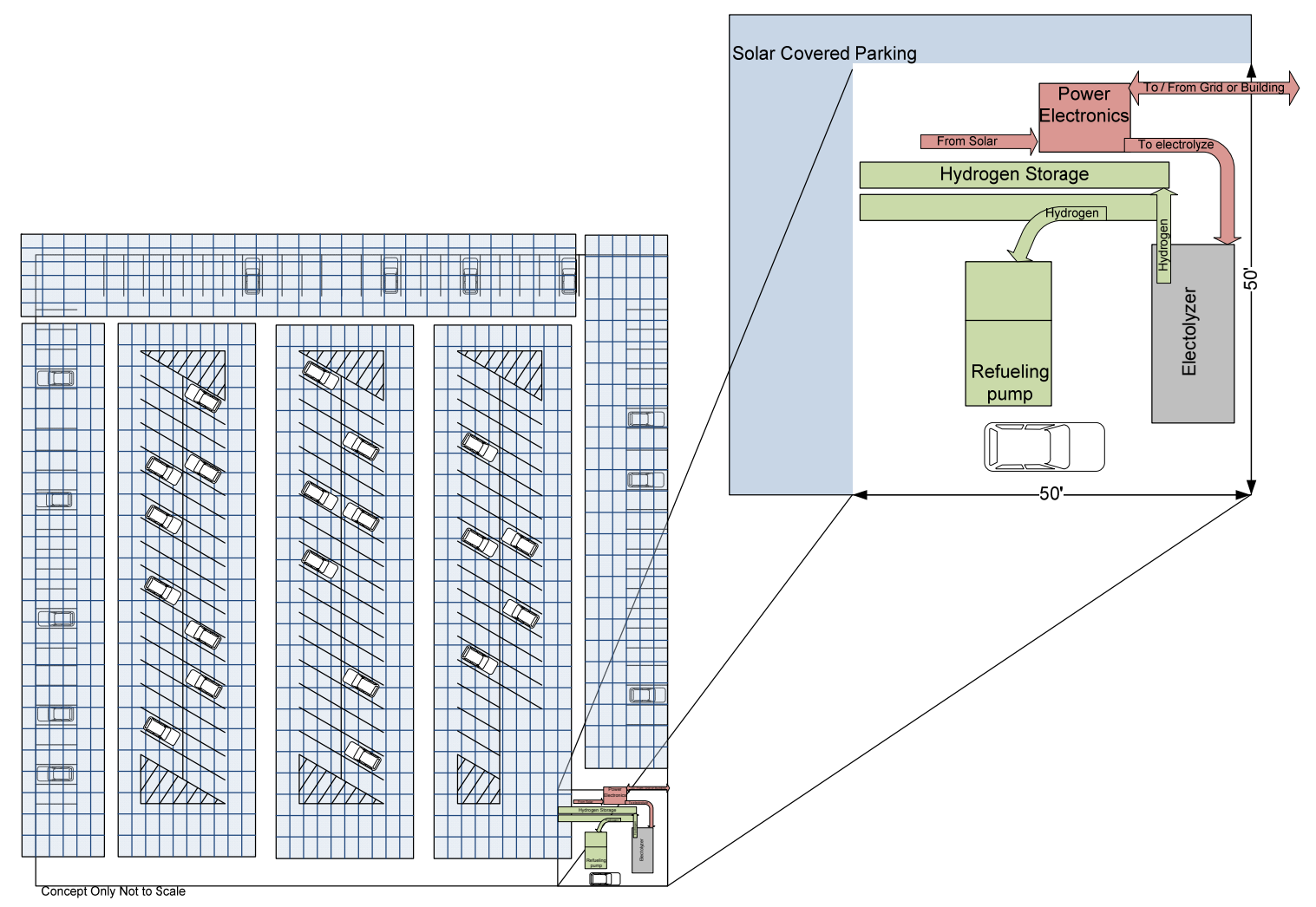

Figure 2. High-level schematic of the proposed $\mathrm{H}_{2}$ fueling station.

This facility is intended to be a flagship-type installation, setting the example and establishing a renewable $\mathrm{H}_{2}$ infrastructure in Hawaii for other government and private entities to follow. The objective is to establish an $\mathrm{H}_{2}$ production concept that can be replicated at other sites throughout the islands to produce affordable $\mathrm{H}_{2}$ at a price comparable to fossil fuels and in a way that the cost of $\mathrm{H}_{2}$ will not vary from station to station.

\subsubsection{Equipment Needs and Commercial Availability}

Simply constructed, the $\mathrm{H}_{2}$ production, storage, and fueling facility will consist of the following:

1. A 1.4-acre covered parking lot

2. A 700-kW capacity array of roof-mounted fixed tilt PV solar panels over the Fort Armstrong (HI0013zz) parking lot, with integrated connections to the $\mathrm{H}_{2}$ production capability and to the $\mathrm{HECO}$ electrical grid

3. A polymer electrolyte membrane electrolyzer capable of generating up to $65 \mathrm{~kg}$ of $\mathrm{H}_{2}$ per day

4. One or more 70-kg $\mathrm{H}_{2}$ storage tanks, including all necessary piping to move $\mathrm{H}_{2}$ from the electrolyzer to the tanks and from the tanks to the dispensing station

5. Hydrogen compressor to move $\mathrm{H}_{2}$ from the electrolyzer to the bulk $\mathrm{H}_{2}$ storage tanks 
6. A single, dual-pressure, fast-fill dispenser with chiller capable of dispensing $\mathrm{H}_{2}$ at 350 and 700 bar pressure (provisions will also be made for additional future pump(s) as demand increases).

All required equipment is commercially available, can be easily procured, and installed within a lead time of one calendar year.

\section{ECONOMIC EVALUATION}

\subsection{Capital Equipment and Facility Development Costs}

The necessary equipment identified in Section 3.3.2 constitutes the capital equipment needed to build the $\mathrm{H}_{2}$ fueling station. Capital expenses are calculated based on the cost required to produce a single $\mathrm{kW}$ of power. For the PV solar panels, that is $\$ 4,000$ per $\mathrm{kW}$ at a capacity of $700 \mathrm{~kW}$ for a total capital cost of $\$ \mathbf{\$ 3 , 1 5 0 , 0 0 0}$. For the electrolyzer, that is $\$ 3,500$ per kW at a capacity of $187 \mathrm{~kW}$ for a total capital cost of $\mathbf{\$ 6 5 5 , 0 0 0}$. The other identified pieces of equipment are at their net present purchase price (shown in Table 4). Total capital equipment and facility development costs are estimated at $\mathbf{\$ 4 , 9 2 0 , 0 0 0 \text { . }}$

Table 4. Estimated capital equipment costs.

\begin{tabular}{lr}
\hline Capital Equipment & Estimated Cost \\
\hline Solar panels & $\$ 3,150,000$ \\
Electrolyzer & $\$ 655,000$ \\
Storage & $\$ 70,000$ \\
Dispenser + chiller & $\$ 350,000$ \\
Compressor & $\$ 300,000$ \\
Installation \& Permitting & $\$ 370,000$ \\
Parking meter & $\$ 25,000$ \\
Total capital & $\mathbf{\$ 4 , 9 2 0 , 0 0 0}$ \\
\hline
\end{tabular}

\subsection{Operations and Maintenance Costs}

Operations and Maintenance (O\&M) costs for the $\mathrm{H}_{2}$ fueling station are calculated as the total estimated annual maintenance costs for each piece of capital equipment. As shown in Table 5, annual O\&M costs are estimated at $\$ 150,000$ per year.

Table 5. Estimated operations and maintenance costs.

\begin{tabular}{lr}
\hline Capital Equipment & Estimated O\&M Cost \\
\hline Solar panels & $\$ 21,000$ \\
Electrolyzer & $\$ 32,700$ \\
Storage & $\$ 700$ \\
Dispenser \& chiller & $\$ 17,500$ \\
Compressor & $\$ 15,000$ \\
Parking meter & $\$ 5,000$ \\
Training \& Operation Labor & $\$ 58,100$ \\
Total capital & $\mathbf{\$ 1 5 0 , 0 0 0}$ \\
\hline
\end{tabular}

\subsection{Parking Analysis}

The location of the Fort Armstrong (HI0013zz) lot is ideal for paid parking, especially with the current concept of covered parking in Oahu that can be sold for a premium. It is presumed that a parking 
lot of 1.4 acres can provide 175 stalls that could be made available for parking. It is estimated that a $\$ 0.50 /$ hour rate with a maximum of $\$ 6 /$ day would be a reasonable price to pay for such parking. Currently, there is no covered parking at the Fort Armstrong (HI0013zz) site; however, Prince Jonah Kuhio Kalanianaole covered parking is sold for $\$ 2,760$ per year (i.e., a prorated price of $\$ 7.56$ per day rate). For this analysis, it is presumed that revenue generated with the parking would go to the project net present value (NPV) and the initial rate of return (IRR). Figure 3 shows the NPV and IRR based on the percentage of stalls occupied per year.

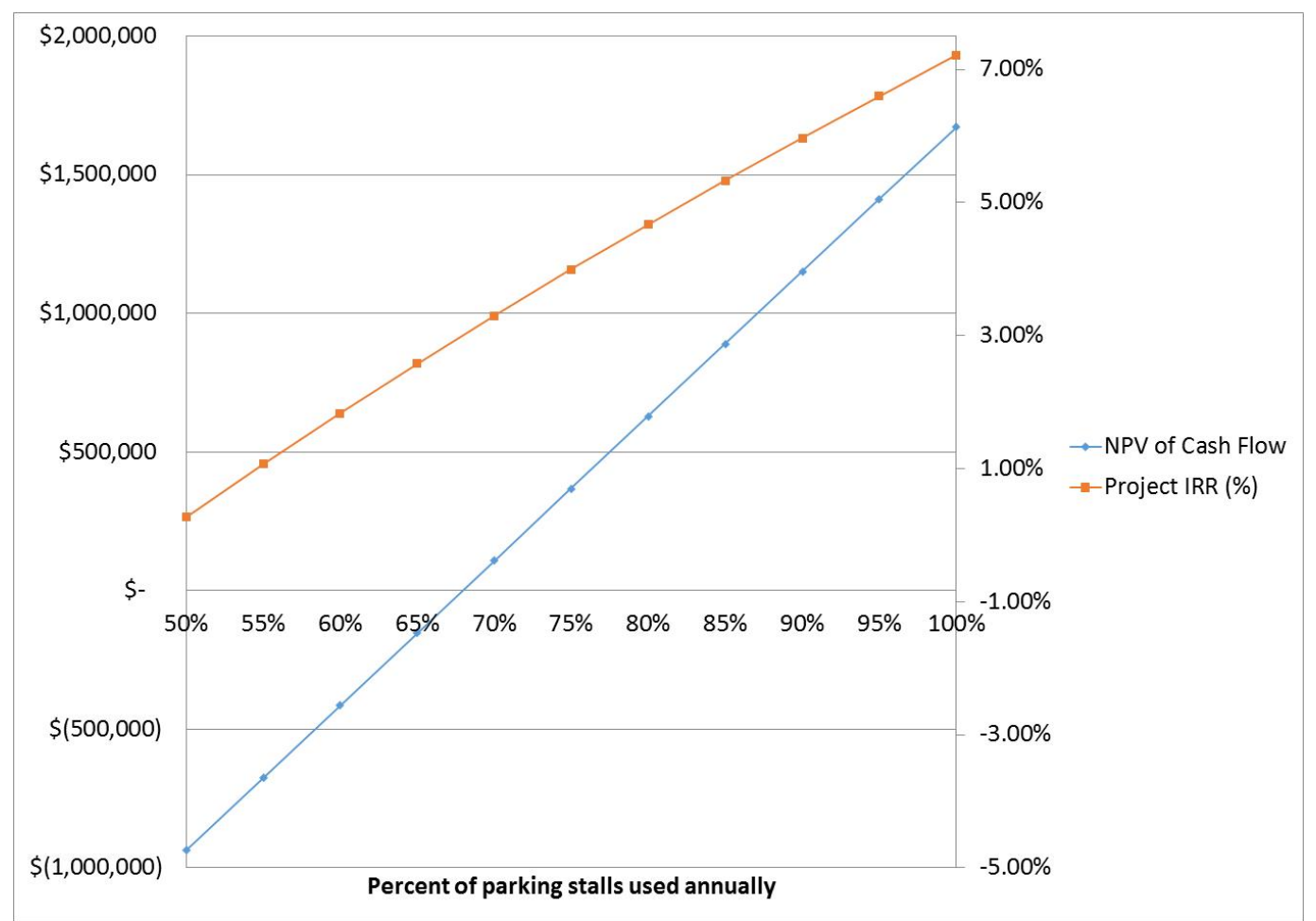

Figure 3. Estimated net present value and initial rate of return versus the percentage of annual parking stalls used.

\subsection{Income and Expenditure Projections (15 years)}

Expenditure projections for the $\mathrm{H}_{2}$ fueling station consist of three items: (1) up-front capital equipment costs $(\$ 4,920,000$; see Table 4$)$, (2) O\&M costs $(\$ 150,000 /$ year; see Table 5), and (3) the cost of purchasing electricity from $\mathrm{HECO}$ for $\mathrm{H}_{2}$ production, escalated over a 15 -year period. The amount of energy needed to produce $1 \mathrm{~kg}$ of $\mathrm{H}_{2}$ is estimated at about $70 \mathrm{kWh} / \mathrm{kg}$. The station will not be fully utilized during the first year, but it is expected that the demand for $\mathrm{H}_{2}$ would ramp up as more vehicles begin to fuel at this location. The demand is projected to reach $52 \mathrm{~kg} /$ day $(18,980 \mathrm{~kg} /$ year $)$ and require 1,300 MWh of electricity. This is the same amount of power available from the $700-\mathrm{kW}$ solar array, which yields 1,300 MWh/year. To minimize capital expense, a 190-kW electrolyzer system will be used instead of a 700-kW electrolyzer. This system operates directly from solar power during the day, with the remaining power (i.e., $680 \mathrm{MWh}$ ) supply generated by the solar array being used by an adjacent facility. At this facility, the solar power displaces energy use at a cost of $\$ 0.30 / \mathrm{kWh}$, yielding a revenue of $\$ 200,000$ annually, assuming 2\% escalation (see Appendix A for the cash flow calculation). The 190-kW electrolyzer will operate continuously, and at night, would consume $700 \mathrm{MWh}$ from the grid at a cost of $30 \notin / \mathrm{kWh}$, yielding an expense of $\$ 211,000$ per year. The system effectively is a net-zero grid power consumer because it overproduces the same amount of daytime energy that it consumes at night. The 
revenue from electricity sales matches the expense from grid electricity purchases throughout the year. Total anticipated expenditures over a 15-year period are shown in Table 6.

Income to the project comes from three sources: (1) the sale of excess, solar-based electricity to a thirdparty electricity consumer at the same price they would pay to buy electricity from HECO, (2) the sale of $\mathrm{H}_{2}$ to government and public consumers, and (3) premium covered parking. The third-party consumer is anticipated to purchase about $683,000 \mathrm{kWh}$ of solar-based electricity per year to meet facility needs. At the HECO equivalent price of $\$ 0.30$ per $\mathrm{kWh}$, this equates to a revenue of $\$ 204,900$ once the fueling station is at capacity, with an expected annual revenue increase of $2 \%$ each year thereafter for a total of about $\$ 6,684,219$ in net cash flow after 15 years. Electricity demand profiles indicate that the excess electricity that could be sold to the grid at $\$ 0.197$ per $\mathrm{kWh}$ is negligible (i.e., on the order of less than 10 $\mathrm{kW} /$ year) -- thus it is an immaterial source of potential income. Assuming that $75 \%$ of the lot is full on a continuous basis, premium covered parking will produce $\$ 287,438$ annually for a 15 -year total of $\$ 4,311,563$. The sale of $\mathrm{H}_{2}$ accounts for the remaining revenue. The estimated sale price of $\mathrm{H}_{2}$ is addressed in Section 4.5, with the total anticipated revenue and net cash flow from all sources over a 15-year period being shown in Table 7. It is anticipated that the sales of $\mathrm{H}_{2}$ will increase each year for the first 2 years, showing the transition from gasoline-powered vehicles to fuel cell electric vehicles (FCEVs). It is worth noting that the net cash flow decreases as $\mathrm{H}_{2}$ sales ramp up. This is because, per $\mathrm{kWh}$ of solar power, it is more profitable to sell electrons directly than to produce and sell $\mathrm{H}_{2}$. 
Table 8 is for reference and is used to support the expenditure and income tables; it also shows the assumed energy flow for each year.

\subsection{Price Point of $\mathrm{H}_{2}$}

The price point of $\mathrm{H}_{2}$ for this study is $\$ 13.00 / \mathrm{kg}$. That cost is based upon a comparable price of gasoline for same amount of miles driven. Both the NPV and IRR are sensible at this price point as well. It represents a reasonable cost at which $\mathrm{H}_{2}$ must be sold to recuperate both capital expenditures and O\&M costs following the sale of solar-based power to the grid and the revenue received for parking. Total capital expenses and remaining net O\&M costs are calculated considering the Federal Guidance discount rate of 3\% over a 15 year period. Given the anticipated expenditures and revenues (shown in Tables 6 and 7), the desire to make the sale of $\mathrm{H}_{2}$ a profitable business alternative seems to be achievable. 
Table 6. Total anticipated expenditures (U.S. dollars).

\begin{tabular}{|c|c|c|c|c|c|c|c|c|c|c|c|c|c|c|c|c|}
\hline Source & Yr 0 & Yr 1 & Yr 2 & Yr 3 & Yr 4 & Yr 5 & Yr 6 & Yr 7 & Yr 8 & Yr 9 & Yr 10 & Yr 11 & Yr 12 & Yr 13 & Yr 14 & Yr 15 \\
\hline Grid to $\mathrm{H}_{2}$ & - & $\$ 51,992$ & $\$ 114,842$ & $\$ 219,603$ & $\$ 223,995$ & $\$ 228,475$ & $\$ 233,045$ & $\$ 237,706$ & $\$ 242,460$ & $\$ 247,309$ & $\$ 252,255$ & $\$ 257,300$ & $\$ 262,446$ & $\$ 267,695$ & $\$ 273,049$ & $\$ 278,510$ \\
\hline $\begin{array}{c}\text { Cost of } \\
\text { Maintenance }\end{array}$ & - & $\$ 150,000$ & $\$ 153,000$ & $\$ 156,060$ & $\$ 159,181$ & $\$ 162,365$ & $\$ 165,612$ & $\$ 168,924$ & $\$ 172,303$ & $\$ 175,749$ & $\$ 179,264$ & $\$ 182,849$ & $\$ 186,506$ & $\$ 190,236$ & $\$ 194,041$ & $\$ 197,922$ \\
\hline $\begin{array}{l}\text { Equipment } \\
\text { Expense }\end{array}$ & $\$ 4,919,063$ & $\$-$ & $\$-$ & $\$-$ & $\$-$ & $\$-$ & $\$-$ & \$- & $\$-$ & \$- & \$- & $\$-$ & \$- & $\$-$ & $\$-$ & $\$-$ \\
\hline $\begin{array}{c}\text { Total } \\
\text { Expenditures }\end{array}$ & $\$ 4,919,063$ & $\$ 201,992$ & $\$ 267,842$ & $\$ 375,663$ & $\$ 383,176$ & $\$ 390,840$ & $\$ 398,657$ & $\$ 406,630$ & $\$ 414,763$ & $\$ 423,058$ & $\$ 431,519$ & $\$ 440,149$ & $\$ 448,952$ & $\$ 457,931$ & $\$ 467,090$ & $\$ 476,432$ \\
\hline
\end{tabular}

Table 7. Total anticipated income (U.S. dollars).

\begin{tabular}{|c|c|c|c|c|c|c|c|c|c|c|c|c|c|c|c|c|}
\hline Source & Yr 0 & Yr 1 & Yr 2 & Yr 3 & Yr 4 & Yr 5 & Yr 6 & Yr 7 & Yr 8 & Yr 9 & Yr 10 & Yr 11 & Yr 12 & Yr 13 & Yr 14 & Yr 15 \\
\hline $\mathrm{H}_{2}$ Sales & - & $\$ 82,247$ & $\$ 167,783$ & $\$ 256,708$ & $\$ 261,842$ & $\$ 267,079$ & $\$ 272,421$ & $\$ 277,869$ & $\$ 283,427$ & $\$ 289,095$ & $\$ 294,877$ & $\$ 300,775$ & $\$ 306,790$ & $\$ 312,926$ & $\$ 319,184$ & $\$ 325,568$ \\
\hline Parking & - & $\$ 287,438$ & $\$ 293,186$ & $\$ 299,050$ & $\$ 305,031$ & $\$ 311,132$ & $\$ 317,354$ & $\$ 323,701$ & $\$ 330,175$ & $\$ 336,779$ & $\$ 343,514$ & $\$ 350,385$ & $\$ 357,392$ & $\$ 364,540$ & $\$ 371,831$ & $\$ 379,268$ \\
\hline $\mathrm{PV}$ to $3^{\text {rd }}$ Party & $\$-$ & $\$ 307,392$ & $\$ 241,998$ & $\$ 213,207$ & $\$ 217,471$ & $\$ 221,821$ & $\$ 226,257$ & $\$ 230,782$ & $\$ 235,398$ & $\$ 240,106$ & $\$ 244,908$ & $\$ 249,806$ & $\$ 254,802$ & $\$ 259,898$ & $\$ 265,096$ & $\$ 270,398$ \\
\hline $\begin{array}{c}\text { Total } \\
\text { Revenues }\end{array}$ & \$- & $\$ 677,077$ & $\$ 702,967$ & $\$ 768,965$ & $\$ 784,344$ & $\$ 800,032$ & $\$ 816,032$ & $\$ 832,352$ & $\$ 849,000$ & $\$ 865,980$ & $\$ 883,299$ & $\$ 900,966$ & $\$ 918,984$ & $\$ 937,364$ & $\$ 956,111$ & $\$ 975,234$ \\
\hline $\begin{array}{l}\text { Net Cash } \\
\text { Flows }\end{array}$ & $\$(4,919,063)$ & $\$ 475,085$ & $\$ 435,125$ & $\$ 393,302$ & $\$ 401,168$ & $\$ 409,192$ & $\$ 417,375$ & $\$ 425,722$ & $\$ 434,237$ & $\$ 442,922$ & $\$ 451,780$ & $\$ 460,817$ & $\$ 470,032$ & $\$ 479,433$ & $\$ 489,021$ & $\$ 498,802$ \\
\hline
\end{tabular}


Table 8. Analysis of $\mathrm{H}_{2}$ fueling station (reference).

\begin{tabular}{|c|c|c|c|c|c|c|c|c|c|c|c|c|c|c|c|c|}
\hline Analysis/Year & Yr 0 & Yr 1 & Yr 2 & Yr 3 & Yr 4 & Yr 5 & Yr 6 & Yr 7 & Yr 8 & Yr 9 & Yr 10 & Yr 11 & Yr 12 & Yr 13 & Yr 14 & Yr 15 \\
\hline $\begin{array}{l}\text { Price of hydrogen } \\
(\$ / \mathrm{kg})\end{array}$ & 12.75 & 13.00 & 13.26 & 13.53 & 13.80 & 14.07 & 14.35 & 14.64 & 14.93 & 15.23 & 15.54 & 15.85 & 16.16 & 16.49 & 16.82 & 17.15 \\
\hline $\begin{array}{l}\text { Price of } \\
\text { electricity to grid } \\
(\$ / \mathrm{kWh})\end{array}$ & 0.193 & 0.197 & 0.201 & 0.205 & 0.209 & 0.213 & 0.218 & 0.222 & 0.226 & 0.231 & 0.235 & 0.240 & 0.245 & 0.250 & 0.255 & 0.260 \\
\hline $\begin{array}{c}\text { Price of } \\
\text { electricity to } \\
\text { building }(\$ / \mathrm{kWh})\end{array}$ & 0.294 & 0.300 & 0.306 & 0.312 & 0.318 & 0.325 & 0.331 & 0.338 & 0.345 & 0.351 & 0.359 & 0.366 & 0.373 & 0.380 & 0.388 & 0.396 \\
\hline $\begin{array}{c}\text { Hydrogen sales } \\
(\mathrm{kg} / \mathrm{day})\end{array}$ & - & 17 & 35 & 52 & 52 & 52 & 52 & 52 & 52 & 52 & 52 & 52 & 52 & 52 & 52 & 52 \\
\hline $\begin{array}{c}\text { Hydrogen sales } \\
\text { (kg/year) }\end{array}$ & - & 6,327 & 12,653 & 18,980 & 18,980 & 18,980 & 18,980 & 18,980 & 18,980 & 18,980 & 18,980 & 18,980 & 18,980 & 18,980 & 18,980 & 18,980 \\
\hline $\begin{array}{c}\text { PV output } \\
\text { (kWh/year) }\end{array}$ & - & $1,288,678$ & $1,288,678$ & $1,288,678$ & $1,288,678$ & $1,288,678$ & $1,288,678$ & $1,288,678$ & $1,288,678$ & $1,288,678$ & $1,288,678$ & $1,288,678$ & $1,288,678$ & $1,288,678$ & $1,288,678$ & $1,288,678$ \\
\hline $\begin{array}{c}\mathrm{PV} \text { to electrolyzer } \\
\text { (kWh/year) }\end{array}$ & - & 263,220 & 497,756 & 605,576 & 605,576 & 605,576 & 605,576 & 605,576 & 605,576 & 605,576 & 605,576 & 605,576 & 605,576 & 605,576 & 605,576 & 605,576 \\
\hline $\begin{array}{l}\text { PV to } 3^{\text {rd p party }} \\
\text { (kWh/year) }\end{array}$ & - & $1,024,641$ & 790,843 & 683,093 & 683,093 & 683,093 & 683,093 & 683,093 & 683,093 & 683,093 & 683,093 & 683,093 & 683,093 & 683,093 & 683,093 & 683,093 \\
\hline $\begin{array}{c}\mathrm{H}_{2} \text { production } \\
\text { (kg/year) }\end{array}$ & - & 436,528 & 873,056 & $1,309,162$ & $1,309,162$ & $1,309,162$ & $1,309,162$ & $1,309,162$ & $1,309,162$ & $1,309,162$ & $1,309,162$ & $1,309,162$ & $1,309,162$ & $1,309,162$ & $1,309,162$ & $1,309,162$ \\
\hline $\begin{array}{c}\mathrm{H}_{2} \text { from } \mathrm{PV} \\
\text { (kg/year) }\end{array}$ & - & 263,220 & 497,756 & 605,576 & 605,576 & 605,576 & 605,576 & 605,576 & 605,576 & 605,576 & 605,576 & 605,576 & 605,576 & 605,576 & 605,576 & 605,576 \\
\hline $\begin{array}{c}\mathrm{H}_{2} \text { from grid } \\
(\mathrm{kg} / \text { year })\end{array}$ & - & 173,308 & 375,299 & 703,586 & 703,586 & 703,586 & 703,586 & 703,586 & 703,586 & 703,586 & 703,586 & 703,586 & 703,586 & 703,586 & 703,586 & 703,586 \\
\hline $\begin{array}{l}\text { Net grid power } \\
(\mathrm{kWh} / \text { year })\end{array}$ & - & $7,907,850$ & $8,344,378$ & $8,780,484$ & $8,780,484$ & $8,780,484$ & $8,780,484$ & $8,780,484$ & $8,780,484$ & $8,780,484$ & $8,780,484$ & $8,780,484$ & $8,780,484$ & $8,780,484$ & $8,780,484$ & $8,780,484$ \\
\hline $\begin{array}{l}\text { Electricity from } \\
\text { grid (kWh/year) }\end{array}$ & - & $7,908,667$ & $8,344,456$ & $8,780,492$ & $8,780,492$ & $8,780,492$ & $8,780,492$ & $8,780,492$ & $8,780,492$ & $8,780,492$ & $8,780,492$ & $8,780,492$ & $8,780,492$ & $8,780,492$ & $8,780,492$ & $8,780,492$ \\
\hline $\begin{array}{l}\text { Building demand } \\
\text { (kWh/year) }\end{array}$ & - & $8,760,000$ & $8,760,000$ & $8,760,000$ & $8,760,000$ & $8,760,000$ & $8,760,000$ & $8,760,000$ & $8,760,000$ & $8,760,000$ & $8,760,000$ & $8,760,000$ & $8,760,000$ & $8,760,000$ & $8,760,000$ & $8,760,000$ \\
\hline $\begin{array}{l}\mathrm{PV} \text { to building } \\
\text { (kWh/year) }\end{array}$ & - & $1,024,641$ & 790,843 & 683,093 & 683,093 & 683,093 & 683,093 & 683,093 & 683,093 & 683,093 & 683,093 & 683,093 & 683,093 & 683,093 & 683,093 & 683,093 \\
\hline Grid to building & - & $7,735,359$ & $7,969,157$ & $8,076,907$ & $8,076,907$ & $8,076,907$ & $8,076,907$ & $8,076,907$ & $8,076,907$ & $8,076,907$ & $8,076,907$ & $8,076,907$ & $8,076,907$ & $8,076,907$ & $8,076,907$ & $8,076,907$ \\
\hline
\end{tabular}


Figure 4 illustrates the relationship between the NPV and the IRR on the y-axis and the percent of parking occupancy on the $\mathrm{x}$-axis, while holding the cost of $\mathrm{H}_{2}$ constant at $\$ 13.00 / \mathrm{kg}$. The NPV is $\$ 370,000$ and the IRR is $4 \%$. It is presumed that the parking will be at a $75 \%$ occupancy rate. Additional, the NPV and the IRR are highly dependent on the parking revenue. Therefore, when parking occupancy rises, the NPV and IRR become more attractive.

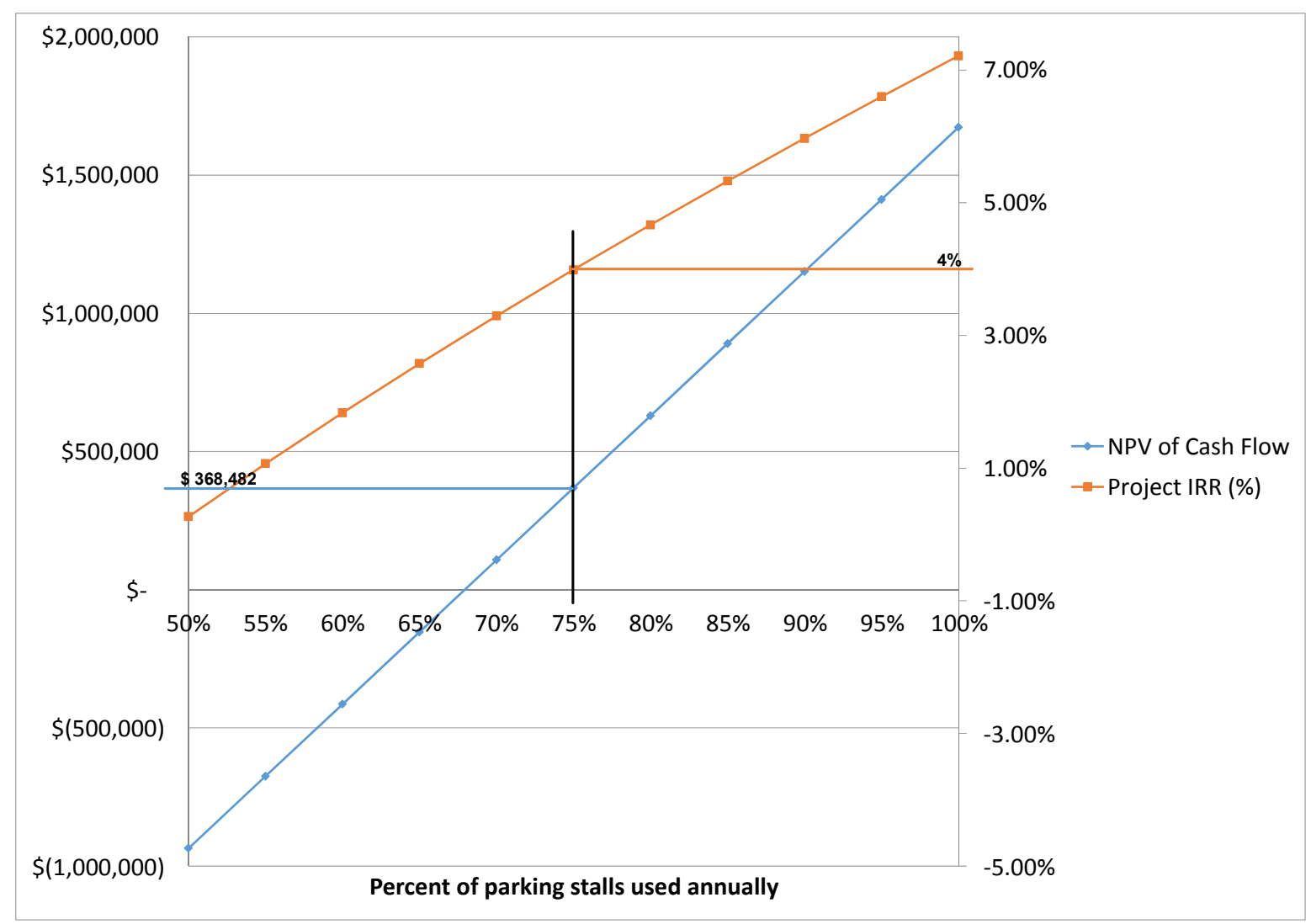

Figure 4 . The net present value and initial rate of return for $75 \%$ parking occupancy.

\subsection{Anticipated Cost to Customer}

As discussed in Section 4.5, the anticipated cost to the customer for $\mathrm{H}_{2}$ produced at the proposed $\mathrm{H}_{2}$ fueling station at Fort Armstrong (HI0013zz) is $\$ 13.00 / \mathrm{kg}$. A single $\mathrm{kg}$ of $\mathrm{H}_{2}$ will power an $\mathrm{H}_{2}$ fuel cell vehicle approximately 80 miles. Considering that gas-powered cars average approximately $24 \mathrm{miles}$ per gallon in fuel economy, a single $\mathrm{kg}$ of $\mathrm{H}_{2}$ is roughly equivalent to 3.3 gallons of gasoline. The current average price of unleaded gasoline in Honolulu, Hawaii is about $\$ 4.35 /$ gallon (HonoluluGasPrices.com, 2014). At $\$ 13.00 / \mathrm{kg}, \mathrm{H}_{2}$ has a gasoline gallon equivalent price of $\$ 3.90$ per gallon. This makes filling a vehicle with $\mathrm{H}_{2}$ slightly less expensive than traditional gasoline under the fueling station concept and configuration presented herein. This type of savings can encourage consumers to purchase and drive $\mathrm{H}_{2}$ powered vehicles.

\subsection{Additional Non-Economic Benefits}

Beyond the economic factors associated with $\mathrm{H}_{2}$ production and distribution, an $\mathrm{H}_{2}$ fueling station in Honolulu, Hawaii, offers the following important benefits:

1. Supports the President's clean energy strategy to reduce greenhouse gas emissions, reduce dependence on foreign oil, and place 1 million electric vehicles on the road 
2. Supports the State of Hawaii Hydrogen Roadmap (2011)

3. Supports both the Hawaii $\mathrm{H}_{2}$ Initiative $\left(\mathrm{H}_{2} \mathrm{I}\right)$ and $\mathrm{H}_{2} \mathrm{USA}$, the public, private partnership (PPP) launched by DOE and industry in 2013 to address the challenge of $\mathrm{H}_{2}$ infrastructure

4. Establishes federal/GSA leadership in the zero emission vehicle (ZEV) and FCEV arena

5. Permits the leasing of FCEVs by GSA on Oahu

6. Informs potential stakeholders that $\mathrm{H}_{2}$ fueling stations are real and encourages the appropriation and allocation of funds for other ZEVs beyond just battery electric vehicles

7. Fort Armstrong (HI0013zz) becomes the 'anchor tenant' for fuel cell vehicle growth and catalyzes development of the Oahu infrastructure toward an initial rollout of six public $\mathrm{H}_{2}$ fueling stations

8. Sends a serious message to FCEV automakers to support the growing demand for ZEVs/FCEVs in Hawaii.

\section{CONCLUSION/RECOMMENDED PATH FORWARD}

It is recommended that the program pursue the detailed design and implementation of an $\mathrm{H}_{2}$ fueling station at the Fort Armstrong (HI0013zz) site in Honolulu, Hawaii.

\subsection{Further Analyses Needed}

Further analysis is needed before going into the detailed design of the $\mathrm{H}_{2}$ fueling station. The following is a list of topics that need further analysis:

- Coordinate with HECO to ensure the grid tie with the PV solar array is acceptable

- Study the options and possibility of partnering with an adjacent Federal facility to determine if that assumption is accurate

- Validate the other assumptions used in this assessment

- Further analyze the rollout and demand for $\mathrm{H}_{2}$ vehicles, including partnering with vehicle manufacturers

- Further analyze cost information by talking to equipment suppliers

- Study options for required permitting.

\subsection{Project Schedule (Notional)}

Table 9 shows a preliminary and notional schedule for the detailed design and construction of an $\mathrm{H}_{2}$ fueling station at the Fort Armstrong (HI0013zz) site in Honolulu, Hawaii. 
Table 9. Preliminary schedule.

\begin{tabular}{|c|c|c|c|c|c|c|c|c|c|c|c|c|c|c|}
\hline \multirow{2}{*}{$\begin{array}{c}\text { Project Schedule } \\
\text { Tasks } \\
\end{array}$} & \multicolumn{2}{|c|}{ FY 2014} & \multicolumn{4}{|c|}{ FY 2015} & \multicolumn{4}{|c|}{ FY 2016} & \multicolumn{4}{|c|}{ FY 2017} \\
\hline & Q3 & Q4 & Q1 & Q2 & Q3 & Q4 & Q1 & Q2 & Q3 & Q4 & Q1 & Q2 & Q3 & Q4 \\
\hline \multicolumn{15}{|l|}{ Planning } \\
\hline \multicolumn{15}{|l|}{ Design } \\
\hline \multicolumn{15}{|l|}{ Siting } \\
\hline \multicolumn{15}{|l|}{ Solar Design } \\
\hline \multicolumn{15}{|l|}{ Electrical Design } \\
\hline \multicolumn{15}{|l|}{$\mathrm{H}_{2}$ System Design } \\
\hline \multicolumn{15}{|l|}{ Preliminary Design } \\
\hline \multicolumn{15}{|l|}{ Final Design } \\
\hline \multicolumn{15}{|l|}{ Procurement } \\
\hline \multicolumn{15}{|l|}{ Construction } \\
\hline \multicolumn{15}{|l|}{ Parking Lot Construction } \\
\hline \multicolumn{15}{|l|}{ Solar Construction } \\
\hline \multicolumn{15}{|l|}{ Electrical Construction } \\
\hline \multicolumn{15}{|l|}{$\mathrm{H}_{2}$ System Construction } \\
\hline \multicolumn{15}{|l|}{ System Integration } \\
\hline \multicolumn{15}{|c|}{ Estimated Substantial Completion } \\
\hline \multicolumn{15}{|l|}{ Turn Over - Final Completion } \\
\hline Operation & & & & & & & & & & & & & & \\
\hline
\end{tabular}




\section{Appendix A \\ Financial Analysis of an $\mathrm{H}_{2}$ Fueling Station at Fort Armstrong (HI0013zz)}

This appendix discusses the analysis steps taken to assess the anticipated financial performance of a renewable $\mathrm{H}_{2}$ fueling station at Fort Armstrong (HI0013zz). The analysis performs the following general steps:

- Time-of-day data incorporation (i.e., fueling demand, solar demand, and building load demand)

- Equipment sizing (i.e., solar panels, electrolyzer, and hydrogen storage)

- Multi-year hourly energy analysis (i.e., accounts for demand ramp-up over time)

- Revenue and expenses tracking

- Multi-year financial analysis.

Analysis for this project requires consideration of the time dependence of the solar resource and fueling demand. For this reason, a detailed model was produced to account for not only financial performance, but to ensure that time dependencies are addressed. Fueling demand for light-duty vehicles is dependent on time of day. The analysis model used Chevron's fueling stations demand profiles to forecast $\mathrm{H}_{2}$ demand over time. The resulting profile is found in Figure 5 as follows:

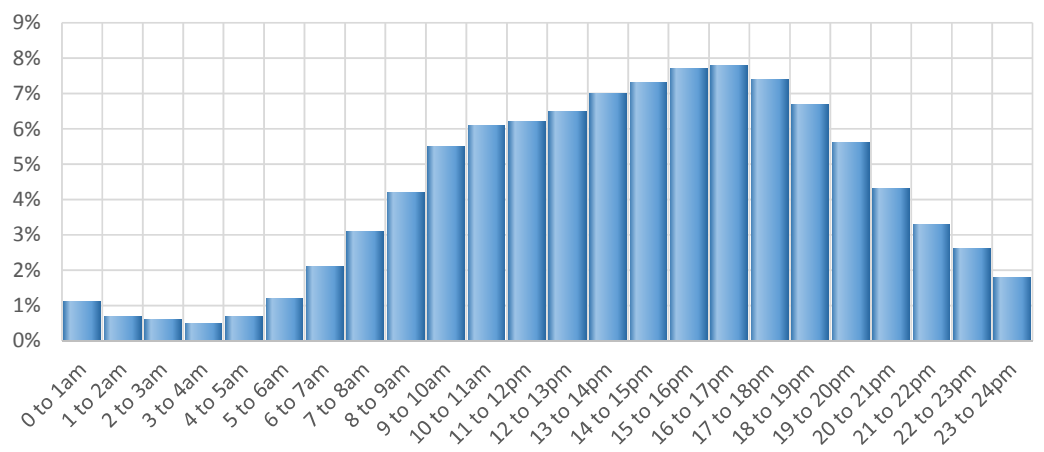

Figure 5: Hourly Demand as Fraction of Daily Hydrogen Demand

As shown, most of fueling would be expected between 4 and 5 pm each day, with very little fueling after $10 \mathrm{pm}$. The profile is repeated each day of the week throughout the year, and also includes variation due to weekly fueling behavior differences, as follows:

\begin{tabular}{l|c|} 
Sunday & $101 \%$ \\
\cline { 2 - 2 } Monday & $94 \%$ \\
\hline Tuesday & $96 \%$ \\
\hline Wednesday & $100 \%$ \\
\hline Thursday & $105 \%$ \\
\hline Friday & $108 \%$ \\
\hline Saturday & $96 \%$ \\
\hline
\end{tabular}

These projections indicate that most fueling occurs on Fridays, although the analysis includes consideration for a larger $\mathrm{H}_{2}$ buffer (in case of production equipment outage) or extended times of elevated $\mathrm{H}_{2}$ demand due to special events (such as nearby station outage or traffic abnormalities). 
Considering the site constraints described below, the site was estimated to be able to support a total of $65 \mathrm{~kg} /$ day of $\mathrm{H}_{2}$ production (where $1 \mathrm{~kg}$ is equivalent to the energy content of 1 gallon of gasoline). Utilization of $\mathrm{H}_{2}$ was assumed to ramp up to full capacity over the first 3 years of operation, with a maximum anticipated utilization of $80 \%$ (52 kg/day).

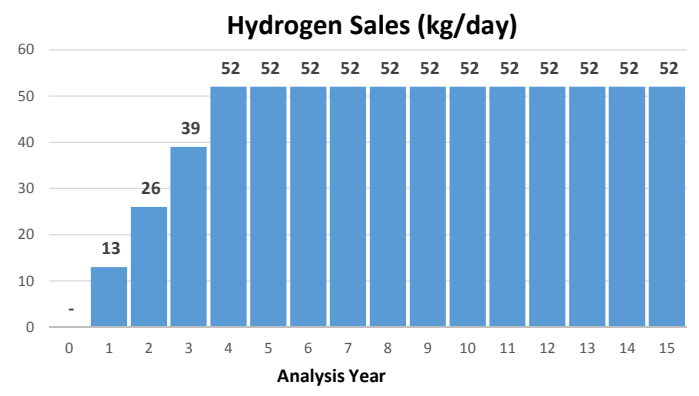

Because the station relies on solar energy for $\mathrm{H}_{2}$ production, data for solar availability was acquired from a weather station at the Honolulu Airport, which is representative of solar availability for this adjacent location. The analysis evaluated fixed-mount panels and single-axis tracking panels. While the tracking system resulted in better electricity production efficiency, it also resulted in less production for the Fort Armstrong (HI0013zz) site. This is due to a higher installation density of fixed panels because they do not shade each other in the mornings and evenings. With the footprint limits of the site, $700 \mathrm{~kW}$ of solar installation was deemed possible. Alternatively, a single-axis tracking system would have yielded only $290 \mathrm{~kW}$ of power for the site and would not have been feasible for a covered parking installation (thus eliminating the potential for parking revenue).

At times, the solar power exceeds the electrolyzer energy demand and at other times is not sufficient. When solar availability exceeds $\mathrm{H}_{2}$ production requirements, electricity is exported from the site. When electrolyzer demand exceeds solar availability, electricity is purchased from the grid. However, excess electricity cannot be sold back to the grid at the retail rate. Commercial grid electricity costs $\$ 0.30 / \mathrm{kWh}$, but selling back to the grid yields only $\$ 0.20 / \mathrm{kWh}$ (according to net metering arrangements established by HECO). To improve the value of excess electricity, this project will pursue a power sharing arrangement with a neighboring facility (possibly a Federal facility). Instead of selling excess electricity to the grid for a reduced price, the power would be used to displace grid purchases by a neighboring building, thus yielding $\$ 0.30 / \mathrm{kWh}$ of avoided costs.

For analysis purposes, a 1,000-kW average demand building load was assumed, with an hourly demand profile consistent for an office building in the appropriate climate type. Hourly energy analysis was performed for each year of the project. The following are examples of analysis outputs for key energy flows, because they vary throughout one analysis year.

Capital cost estimates were made for each system component, as shown in the following table. The component cost estimates reflect recent costs communicated to the National Renewable Energy Laboratory from field installations and maintenance costs experienced by those installations. 
Capital costs

O\&M

\begin{tabular}{|l|lr|l|lr|l|}
\hline Solar pannels & $\$$ & $3,150,000$ & $\$$ & $\$$ & 21,000 & $\$ /$ year \\
\hline Electrolyzer & $\$$ & 3,500 & $\$ / \mathrm{kW}$ & & & \\
\hline Electrolyzer & $\$$ & 654,063 & $\$$ & $\$$ & 32,699 & $\$ /$ year \\
\hline Storage & $\$$ & 70,000 & $\$$ & $\$$ & 700 & $\$ /$ year \\
\hline Dispenser + chiller & $\$$ & 350,000 & $\$$ & $\$$ & 17,500 & $\$ /$ year \\
\hline Compressor & $\$$ & 300,000 & $\$$ & $\$$ & 15,000 & $\$ /$ year \\
\hline Installation \& permitting & $\$$ & 370,000 & $\$$ & $\$$ & 58,101 & $\$ /$ year \\
\hline Parking Meter & $\$$ & 25,000 & $\$$ & $\$$ & 5,000 & $\$ /$ year \\
\hline Total capital & $\$$ & $4,919,063$ & $\$$ & $\$$ & 150,000 & $\$ /$ year \\
\hline
\end{tabular}

PV output

Time of day $\downarrow$ 0 to $1 \mathrm{am}$

1 to $2 a \mathrm{am}$

2 to $3 \mathrm{am}$

3 to $4 \mathrm{am}$

4 to $5 a m$

5 to $6 a \mathrm{~m}$

6 to $7 \mathrm{am}$

7 to $8 \mathrm{am}$

8 to $9 a m$

9 to $10 \mathrm{am}$

10 to $11 \mathrm{am}$

11 to $12 \mathrm{pm}$

12 to $13 \mathrm{pm}$

13 to $14 \mathrm{pm}$

14to $15 \mathrm{pm}$

15 to

16 to $17 \mathrm{pm}$

17 to $18 \mathrm{pm}$

18 to $19 \mathrm{pm}$

19 to $20 \mathrm{pm}$

20 to $21 \mathrm{pm}$

21 to $22 \mathrm{pm}$

22 to $23 \mathrm{pm}$

23 to $24 \mathrm{pm}$

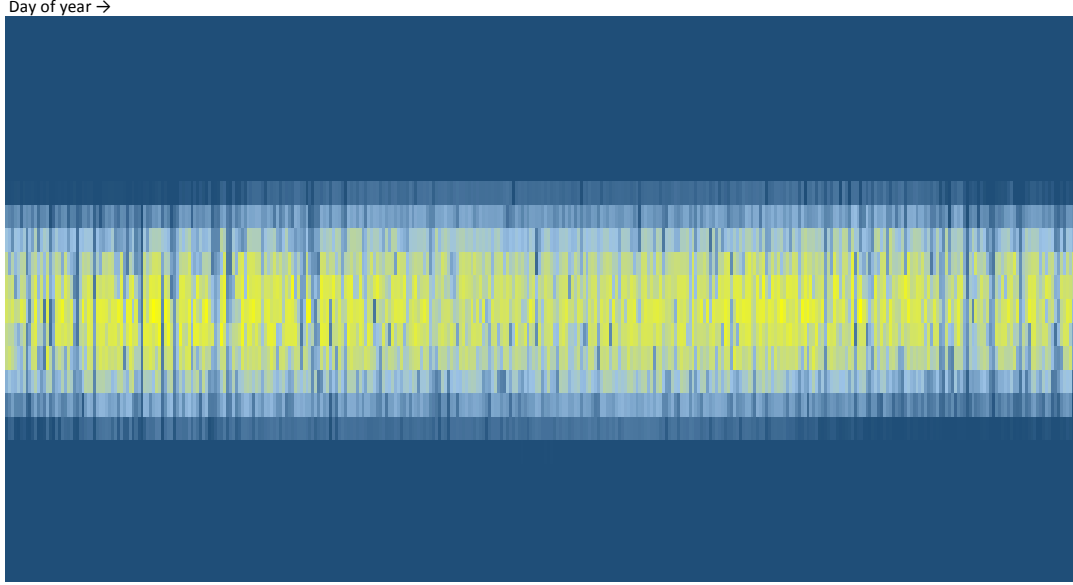

PV to electrolyzer

0 to $1 \mathrm{am}$

1 to 2 am

2 to $3 \mathrm{am}$

3 to $4 a m$

4 to $5 \mathrm{am}$

5 to $6 a m$

8 to $9 \mathrm{am}$

9 to $10 \mathrm{am}$

10 to $11 \mathrm{am}$

11 to $12 \mathrm{pm}$

12 to $13 \mathrm{pm}$

13 to $14 \mathrm{pm}$

14 to $15 \mathrm{pm}$

15 to $16 \mathrm{pm}$

16 to $17 \mathrm{pm}$

16 to $17 \mathrm{pm}$

19 to $20 \mathrm{pm}$

20 to $21 \mathrm{pm}$

21 to $22 \mathrm{pm}$

22 to $23 \mathrm{pm}$

23 to $24 \mathrm{pm}$

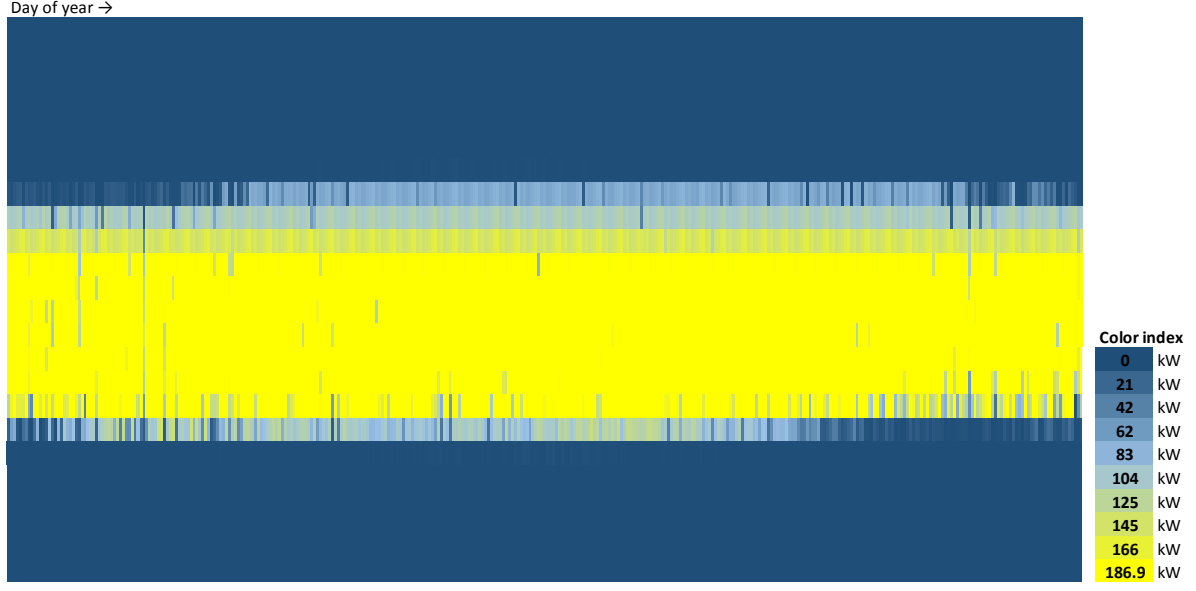




\section{PV to building}

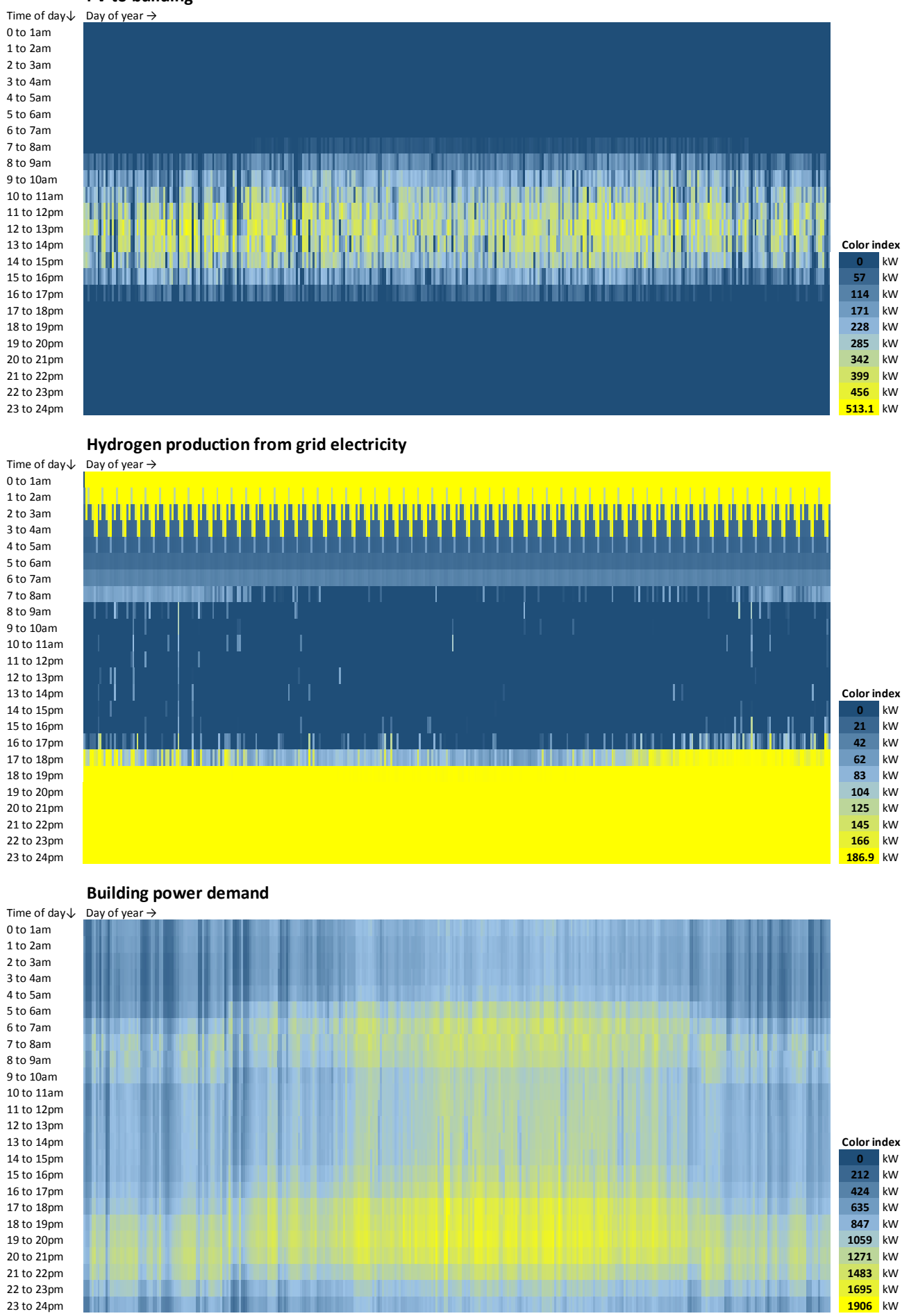

Revenues and expenses were quantified for each project analysis year. Parking revenues were estimated by assuming that, on average, the parking would be $75 \%$ occupied for 12 hours per day at a rate of $\$ 0.50$ /hour for any of its 175 parking spots. This results in an annual income from parking fees of $\$ 287,000$. Hydrogen would be sold for $\$ 13 / \mathrm{kg}$, which is roughly equivalent to $\$ 3.90 /$ gallon of gasoline fuel cost. 


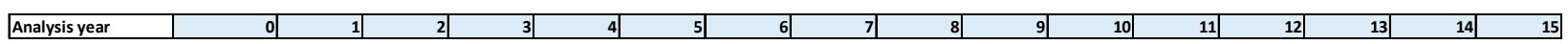

Revenues

\begin{tabular}{|c|c|c|c|c|c|c|c|c|c|c|c|c|c|c|c|c|}
\hline Aydrogen s & - & 82,247 & 167,783 & 256,708 & 261,842 & 267,079 & 272,421 & 277,869 & 283,427 & 289,095 & 294,877 & 300,775 & 306,790 & 312,926 & 319,184 & 325,568 \\
\hline PV to grid & - & 161 & 16 & 2 & 2 & 2 & 2 & 2 & 2 & 2 & 2 & 2 & 2 & 2 & 2 & 2 \\
\hline $\mathrm{Pa}$ & - & 7,438 & 186 & 9,050 & 031 & 132 & 354 & 323,701 & 175 & 336,779 & 343,514 & 385 & 357,392 & 364,540 & 371,831 & 379,268 \\
\hline Pv to building & 13 & $\$ 307,392$ & $\$ 241,998$ & $\$ 213,207$ & $\$ 217,471$ & $\$ 221,821$ & $\$ 226,257$ & $\$ 230,782$ & $\$ 235,398$ & $\$ 240,106$ & $\$ 244,908$ & $\$ 249,806$ & $\$ 254,802$ & $\$ 259,898$ & $\$ 265,096$ & $\$ 270,398$ \\
\hline Total rey & 6 & $\$ 677,237$ & $\$ 702,983$ & $\$ 768,967$ & $\$ 784,346$ & $\$ 800,033$ & $\$ 816,034$ & $\$ 832,355$ & $\$ 849,002$ & $\$ 865,982$ & $\$ 883,301$ & $\$ 900,968$ & $\$ 918,987$ & $\$ 937,367$ & $\$ 956,114$ & $\$ 975,236$ \\
\hline
\end{tabular}

Expendiutes

Expenditures
\begin{tabular}{|l|r|r|r|r|r|r|r|r|r|r|r|r|r|r|r|r|r|}
\hline Grid to H2 & - & 51,992 & 114,842 & 219,603 & 223,995 & 228,475 & 233,045 & 237,706 & 242,460 & 247,309 & 252,255 & 257,300 & 262,446 & 267,695 & 273,049 & 278,510 \\
\hline
\end{tabular}

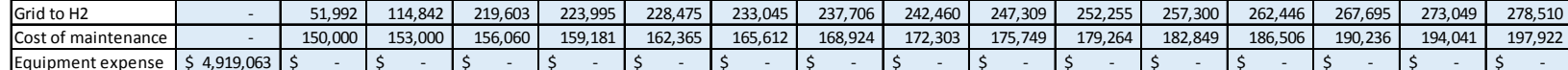

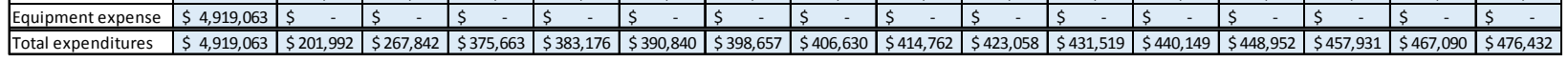

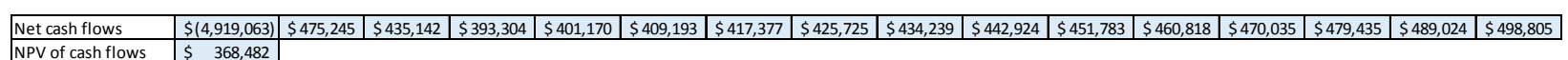
\begin{tabular}{|l|r|}
\hline NPV of cash flows & $\$ 368,482$ \\
\hline Project IRR & $3.99 \%$ \\
\hline
\end{tabular}

Note that in this analysis, equipment is owned and operated by a government entity. This implies that taxes are not paid, thus financial analysis does not require evaluation of depreciation. NPV for the project was evaluated using a discount rate of $3 \%$ and yielded $\$ 300,000$. The project IRR was calculated at $3.9 \%$. 